02 Royal Netherlands Institute for Sea Research

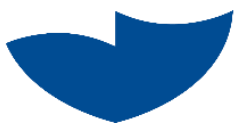

This is a pre-copyedited, author-produced version of an article accepted for publication, following peer review.

Weiss, G.M.; de Bar, M.W.; Stolwijk, D.J.; Schouten, S.; Sinninghe Damsté, J.S. \& van der Meer, M.T.J. (2019). Paleosensitivity of hydrogen isotope ratios of long-chain alkenones to salinity changes at the Chile Margin. Paleoceanography and Paleoclimatology, 34, 978-989

Published version: https://dx.doi.org/10.1029/2019pa003591

NIOZ Repository: http://imis.nioz.nl/imis.php?module=ref\&refid=313355

[Article begins on next page]

The NIOZ Repository gives free access to the digital collection of the work of the Royal Netherlands Institute for Sea Research. This archive is managed according to the principles of the Open Access Movement, and the Open Archive Initiative. Each publication should be cited to its original source - please use the reference as presented.

When using parts of, or whole publications in your own work, permission from the author(s) or copyright holder(s) is always needed. 
Weiss Gabriella, M (Orcid ID: 0000-0002-9571-2558)

de Bar Marijke, Wilhelmina (Orcid ID: 0000-0001-5081-211X)

van der Meer Marcel (Orcid ID: 0000-0001-6454-1752)

\section{Paleosensitivity of hydrogen isotope ratios of long-chain alkenones to salinity changes at the Chile Margin}

G. M. Weiss ${ }^{1}$, M. W. de Bar ${ }^{1}$, D. J. Stolwijk ${ }^{1,2}$, S. Schouten ${ }^{1,2}$, J. S. Sinninghe Damsté ${ }^{1,2}$, and M. T. J. van der Meer ${ }^{1}$

${ }^{1}$ NIOZ, Royal Netherlands Institute for Sea Research, Department of Marine Microbiology and Biogeochemistry, and Utrecht University, Den Burg, 1790 AB, The Netherlands.

${ }^{2}$ Department of Earth Sciences, Faculty of Geosciences, Utrecht University, Utrecht, The Netherlands.

Corresponding author: Gabriella M. Weiss (gabriella.weiss@ nioz.nl)

Key Points:

- Hydrogen isotope ratios of long-chain alkenones track glacial to interglacial climate changes

- Sensitivity of hydrogen isotope ratios of alkenones to salinity is larger in paleo settings than observed in cultures or modern environments

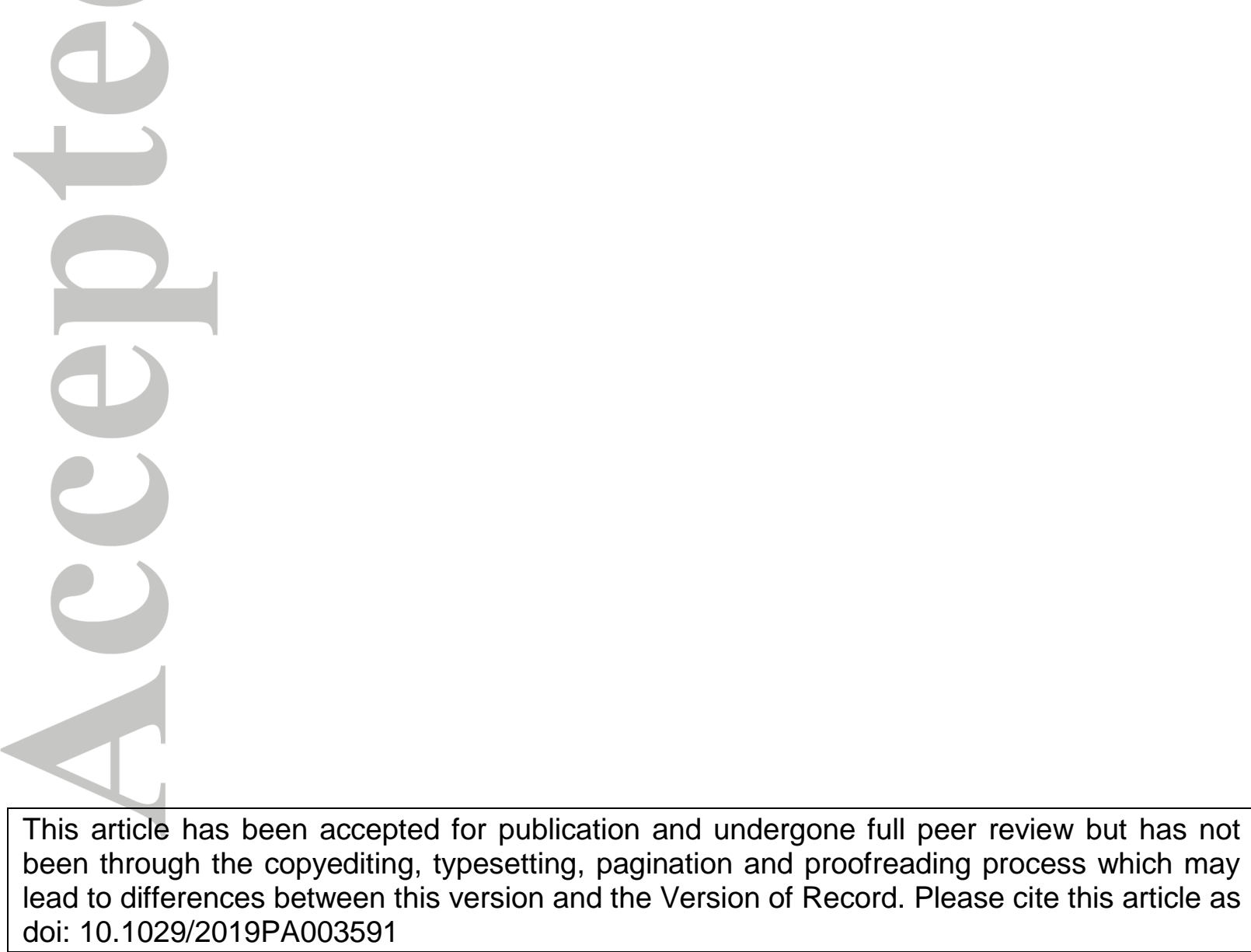

(C) 2019 American Geophysical Union. All rights reserved. 


\section{Abstract}

Hydrogen isotope ratios of long-chain alkenones $\left(\delta^{2} \mathrm{H}_{\mathrm{C} 37}\right.$ ratios) have been shown to correlate with salinity in several culture studies. However, it is uncertain how applicable the $\delta^{2} \mathrm{H}_{\mathrm{C} 37^{-}}$ salinity relationship is to reconstruct past salinity. $\delta^{2} \mathrm{H}_{\mathrm{C} 37}$ ratios were measured on sediments from a drill core (ODP site 1234) at the Chilean Margin covering the last 150 kyr. High $\delta^{2} \mathrm{H}_{\mathrm{C} 37}$ values corresponded to glacial time periods and interglacial periods are characterized by lower $\delta^{2} \mathrm{H}_{\mathrm{C} 37}$ values, aligning with $\delta^{18} \mathrm{O}$ ratios measured on planktonic foraminifera from the same core. Effects of parameters such as species composition, the $\delta^{2} \mathrm{H}-\delta^{18} \mathrm{O}$ relationship used for ice volume corrections, and nutrient or light controlled growth rate, did not appear to significantly alter $\delta^{2} \mathrm{H}_{\mathrm{C} 37}$ ratios at ODP 1234 . We used linear regression equations from batch culture experiments, marine surface sediments, and suspended particulate organic matter to quantitatively characterize salinity changes over the last $150 \mathrm{kyr}$ at ODP 1234 . However, most of these equations yielded larger salinity shifts than previously suggested, a phenomenon also observed for other $\delta^{2} \mathrm{H}_{\mathrm{C} 37}$ records. This suggests that the paleosensitivity of $\delta^{2} \mathrm{H}_{\mathrm{C} 37}$ ratios to salinity was larger in the geologic record than has been observed in any modern environment or laboratory settings, or that glacial to interglacial salinity shifts might have been larger than currently believed.

\section{Key words: Hydrogen isotopes, alkenones, paleosalinity, Chile Margin}

\section{Introduction}

Continental climate is regulated considerably by our global oceans. Ocean circulation transfers heat around the planet as a result of density driven changes caused in part by fluctuations in temperature and salinity (Rahmstorf, 2002). A robust understanding of global and regional climate shifts requires estimates of both parameters. Various organic and inorganic proxies are applied to reconstruct temperature throughout the geologic record 
(Emiliani, 1955; Brassell et al., 1986; Elderfield and Ganssen, 2000; Schouten et al., 2002).

Reconstructions of salinity changes, on the other hand, are more complicated (Rohling,

2007). Inorganic proxies based on foraminiferal calcite include $\mathrm{Ba} / \mathrm{Ca}$ ratios (Weldeab et al., 2007), $\delta^{18} \mathrm{O}$ ratios corrected for calcification temperature using $\mathrm{Mg} / \mathrm{Ca}$ ratios (Duplessy et al., 1991), and $\mathrm{Na} / \mathrm{Ca}$ (Wit et al., 2013; Mezger et al., 2018). Paleosalinity is also inferred from the hydrogen isotope composition of long-chain alkenones $\left(\delta^{2} \mathrm{H}_{\mathrm{C} 37}\right)$, biomarker lipids synthesized by a select group of haptophyte algae of the order Isochrysidales (Marlowe et al., 1984). Marine haptophytes synthesize alkenones with 37 - 39 carbon atoms, and two to four degrees of unsaturation (de Leeuw et al., 1980; Volkman et al., 1980). The ratio of the triunsaturated $\mathrm{C}_{37}$ alkenone to the di-unsaturated $\mathrm{C}_{37}$ alkenone corresponds to changes in temperature, making it a useful proxy for understanding surface ocean temperature anomalies in the past (Brassell et al., 1986; Prahl and Wakeham, 1987). Hydrogen isotope ratios of long-chain alkenones correlated significantly with salinity in laboratory culture experiments, with more enriched isotope ratios corresponding to higher salinities (Schouten et al., 2006;

M'Boule et al., 2014; Sachs et al., 2016; Weiss et al., 2017). These studies have also provided insight about other environmental factors affecting hydrogen isotope fractionation in longchain alkenones $\left(\alpha_{\mathrm{C} 37}\right)$, and how these factors might complicate the salinity signal recorded by alkenone $\delta^{2} \mathrm{H}$ ratios $\left(\delta^{2} \mathrm{H}_{\mathrm{C} 37}\right)$. For example, growth rate, an important variable that affects lipid production, negatively correlated with the hydrogen isotope fractionation factor $\alpha$ (Schouten et al., 2006; Wolhowe et al., 2009; Sachs and Kawka, 2015). When growth was kept constant, the correlation between $\delta^{2} \mathrm{H}_{\mathrm{C} 37}$ ratios and salinity remained (Sachs et al., 2016), suggesting that growth rate might exhibit an insignificant control on $\delta^{2} \mathrm{H}_{\mathrm{C} 37}$ ratios relative to salinity. Irradiance is a vital resource for photosynthesizing organisms like haptophytes, and a parameter that can control algal growth rate. Culture and open ocean datasets showed that irradiance affects $\delta^{2} \mathrm{H}_{\mathrm{C} 37}$ ratios and $\alpha_{\mathrm{C} 37}$ at light intensities below $200 \mu \mathrm{mol}$ photons $\mathrm{m}^{-2} \mathrm{~s}^{-1}$, 
but above 200 the effect is negligible (van der Meer et al., 2015; Wolhowe et al., 2015). In addition to parameters like growth rate and irradiance, different alkenone-producing haptophyte species are known to produce alkenones with different $\delta^{2} \mathrm{H}_{\mathrm{C} 37}$ ratios resulting in distinct $\alpha_{\mathrm{C} 37}$ values under identical growth conditions in both cultures and the natural environment (Schwab and Sachs, 2011; Chivall et al., 2014; M'Boule et al., 2014; Nelson and Sachs, 2014; Weiss et al., 2019). Alkenone producing haptophyte species are genetically divided into three distinct groups: Group I are lacustrine alkenone producers with no cultured representatives at the present inhabiting fresh water and oligohaline lakes (Theroux et al., 2010). Group II haptophytes live in lacustrine to hypersaline lakes and coastal environments, and Group III are open marine species (Theroux et al., 2010). In batch culture, there is approximately $100 \%$ difference between hydrogen isotope ratios of alkenones Group II and III species grown at the same salinity (Chivall et al., 2014; M’Boule et al., 2014). Group III species Emiliania huxleyi and Gephyrocapsa oceanica also diverge (ca $25 \%$ ), but to a lesser degree than observed between Group II and III (Schouten et al., 2006).

Despite the fact that a number of environmental factors affected $\delta^{2} \mathrm{H}_{\mathrm{C} 37}$ ratios in culture, salinity always showed a significant positive correlation with $\delta^{2} \mathrm{H}_{\mathrm{C} 37}$ ratios in cultures (Schouten et al., 2006; M'Boule et al., 2014; Sachs et al., 2016; Weiss et al., 2017). For this reason, $\delta^{2} \mathrm{H}_{\mathrm{C} 37}$ ratios have been used to infer qualitative information about salinity changes in the geologic record (Pahnke et al., 2007; van der Meer et al., 2007, 2008; Leduc et al., 2013; Vasiliev et al., 2013; Kasper et al., 2014, 2015; Petrick et al., 2015; Simon et al., 2015). However, the slopes of the linear regression equations for the relationship between $\delta^{2} \mathrm{H}_{\mathrm{C} 37}$ ratios and salinity vary considerably between culture experiments, ranging from 4.8 (Schouten et al., 2006) to 1.3 (Sachs et al., 2016), equating to a $4.8 \%$ or $1.3 \%$ change in $\delta^{2} \mathrm{H}_{\mathrm{C} 37}$ ratio per practical salinity unit (psu), respectively. Alkenones in marine surface sediments had a $1.3 \%$ response to salinity (Weiss et al., 2019), and alkenones in suspended 
particulate organic matter (SPOM) from the Atlantic and Pacific oceans had a $\delta^{2} \mathrm{H}_{\mathrm{C} 37}-$ salinity response of 4.2 (Gould et al., 2019). These large differences make it difficult to quantitatively constrain past salinity changes.

To understand the sensitivity of the $\delta^{2} \mathrm{H}_{\mathrm{C} 37}$ - salinity relationship in past settings, we measured $\delta^{2} \mathrm{H}_{\mathrm{C} 37}$ ratios on a down-core record from ODP site 1234, off the coast of Chile.

This system is important because of the influence of surface and deep water currents (which cause upwelling and contribute to productivity), freshwater runoff, and southern westerly winds, making this setting a dynamic test site for enhancing our understanding of the controlling factors on $\delta^{2} \mathrm{H}_{\mathrm{C} 37}$ ratios in the geologic record. For example, the convergence of different water masses and the input of continental runoff could potentially be recorded in $\delta^{2} \mathrm{H}_{\mathrm{C} 37}$ values. The site was previously studied for past upwelling conditions and sea surface temperature evolution using long-chain diols and other lipid biomarkers (de Bar et al., 2018), and covers the last $150 \mathrm{kyr}$ and six marine isotope stages (Lisiecki and Raymo, 2005). We compared the ODP $1234 \delta^{2} \mathrm{H}_{\mathrm{C} 37}$ record to other sediment records of $\delta^{2} \mathrm{H}_{\mathrm{C} 37}$ ratios to infer how sensitive $\delta^{2} \mathrm{H}_{\mathrm{C} 37}$ ratios are to past salinity changes overall.

\section{Materials and Methods}

\subsection{Geographic Setting}

The Peru-Chile upwelling system has been the subject of a number of studies (Dugdale et al., 1977; Busch and Keller, 1981; Vargas et al., 2007), and has been referred to as a "one of the world's high productivity regions of great significance" (Marchant et al., 1999). Site ODP $1234\left(36^{\circ} 13.153^{\prime} \mathrm{S}, 73^{\circ} 40.902^{\prime} \mathrm{W}\right)$ was drilled on the continental slope $\sim 70 \mathrm{~km}$ away from the coast at $1015 \mathrm{~m}$ water depth, just off the continental shelf which extends to about $60 \mathrm{~km}$ (Strub et al., 1998). The major currents at this site are the Peru-Chile Countercurrent (PCCC) which flows southward, surrounded on the east by the northward flowing Peru-Chile Current (PCC) and on the west by the northward flowing Chile Coastal Current (CC). The Antarctic 
Circumpolar Current (ACC) feeds into the PCCC and Chilean Fjord Water (CFW) feeds into the CC (Strub et al., 1998; Lamy et al., 2002), potentially adding isotopically depleted water into the system (Fig. 1). Isotopically depleted water is also introduced via freshwater runoff coming from the nearby Río Bio-Bio and Río Itata (Muratli et al., 2010). Upwelling brings the nutrient rich, cold water to the surface, resulting in high productivity (Bakun, 1990). The modern day surface salinity at the site is $33.8 \mathrm{psu}$, with higher salinity of 34.2 psu to the northwest of the site and lower salinity of 33 psu at the south near the Los Lagos region (Mix et al., 2003), covering a range slightly larger than 1 psu for the region.

\subsection{Long-chain alkenones}

Samples were taken in $\sim 2 \mathrm{kyr}$ resolution $(\mathrm{n}=72)$. Age model specifics are described in de Bar et al. (2018), who used a modified version of the age model from Heusser et al. (2006). The age-depth model was constructed based on benthic $\delta^{18} \mathrm{O}$ correlated to the Vostok ice core chronology and core MD95204 from the Atlantic in conjunction with radiocarbon dating. Two age models were constructed for the upper and lower halves of the sections, and these were connected by linear interpolation between ca. 83 to $90 \mathrm{ka}$. Organics were extracted from the sediments and ketone fractions (de Bar et al., 2018) were used for hydrogen isotope measurements of alkenones (Weiss et al., 2019). Hydrogen isotope ratios were measured on alkenones in duplicate using on-column injection on a gas chromatograph coupled to a Thermo Delta V isotope ratio mass spectrometer via a high temperature conversion reactor (Isolink I) and Conflo IV. The GC was equipped with an RTX-200 column (Restek, $60 \mathrm{~m} \mathrm{x}$ $0.32 \mathrm{~mm} \times 0.5 \mu \mathrm{m})$. The $\mathrm{GC}$ temperature program is as follows: $70{ }^{\circ} \mathrm{C}$ to 250 at $18{ }^{\circ} \mathrm{C} / \mathrm{min}$, $250-320{ }^{\circ} \mathrm{C}$ at $1.5^{\circ} \mathrm{C} / \mathrm{min}$, then $320^{\circ} \mathrm{C}$ for $25^{\circ} \mathrm{C} / \mathrm{min}$ at a flow rate of $1.5 \mathrm{~mL} / \mathrm{min}$. The RTX-200 60 m column allows for better separation and determination of isotope ratios of individual alkenones, and thus we report the individual $\mathrm{C}_{37: 3}$ and $\mathrm{C}_{37: 2}$ alkenones, as well as the integrated $\mathrm{C}_{37}$ alkenones. The integrated $\mathrm{C}_{37} \delta^{2} \mathrm{H}$ ratios were determined by a manual 
peak integration combining the two $\mathrm{C}_{37: 3}$ and $\mathrm{C}_{37: 2}$ peaks and used for better comparison with previously published records of $\delta^{2} \mathrm{H}$ ratios which used combined $\mathrm{C}_{37: 3}$ and $\mathrm{C}_{37: 2}$ isotope ratios. The $\mathrm{H}_{3}{ }^{+}$factor was measured and corrected for at the start of each day before measuring standards and samples, and varied from $2.633-3.195 \mathrm{ppm} \mathrm{nA}^{-1}$, with differences of less than $0.1 \mathrm{ppm} \mathrm{nA}^{-1}$ from day to day. To monitor machine performance and stability, an $n$-alkane standard, Mix B (supplied by A. Schimmelmann, Indiana University), was run at the start of each day and samples were only run when the average difference and standard deviation between online and offline values was less than 5\%. Squalane and $\mathrm{C}_{30} n$-alkane were co-injected with each $\delta^{2} \mathrm{H}$ sample run to further monitor machine performance. Values for squalane were $-165 \pm 3 \%$, and $\mathrm{C}_{30}$ were $-75 \pm 4 \%$ over the entire sample set, which fit well with predetermined values of $-170 \pm 4 \%$ and $-79 \pm 5 \%$ respectively. Isotope ratios presented here are based on single-point referencing to a calibrated gas cylinder, and error bars represent the reproducibility between duplicate or triplicate analytical runs.

\subsection{Paleosalinity calculations}

A global ice volume correction for $\delta^{2} \mathrm{H}_{\mathrm{C} 37}$ ratios was taken from the ANICE fully coupled 3D ice-sheet-sea-level model (de Boer et al., 2014). Since the ice volume correction from ANICE is for oxygen isotope ratios, we converted these to hydrogen isotope ratios using the global meteoric water line from Craig and Gordon (1965):

$\delta^{2} \mathrm{H}=8 * \delta^{18} \mathrm{O}+10$

Salinity was calculated from ice volume corrected $\delta^{2} \mathrm{H}_{\mathrm{C} 37}$ ratios using a surface sediment calibration (Weiss et al., 2019):

$\delta^{2} \mathrm{H}_{\mathrm{C} 37}=1.3 * \mathrm{~S}-227$

and, to contrast with the smaller sensitivity, the culture calibration from Schouten et al.

(2006) for Emiliania huxleyi:

$\delta^{2} \mathrm{H}_{\mathrm{C} 37}=4.8 * \mathrm{~S}-347$ 
and the SPOM calibration from Gould et al. (2019):

$\delta^{2} \mathrm{H}_{\mathrm{C} 37}=4.2 * \mathrm{~S}-340$

We selected the Schouten et al. (2006) equation because E. huxleyi is the dominant modern alkenone producing haptophyte in the south eastern Pacific (Hagino and Okada, 2004, 2006). The SPOM calibration represents the environmental $\delta^{2} \mathrm{H}_{\mathrm{C} 37}$ response to salinity in the open ocean at the time of sampling, and therefore captures a snapshot of the marine signal, which can be juxtaposed with the surface sediment calibration.

\section{Results and Discussion}

\subsection{Salinity reconstructions}

$\delta^{2} \mathrm{H}_{\mathrm{C} 37}$ ratios ranged from $-195 \%$ to $-167 \%$, covering a range of $28 \%$ over the last $\sim 150$ kyr at ODP 1234 (Table 1; Fig. 2a). The $\delta^{2} \mathrm{H}_{\mathrm{C} 37}$ ratios correlated well with different marine isotope stages MIS $1-6$, and even the substages of MIS 5 (Fig. 2a). The most enriched $\delta^{2} \mathrm{H}_{\mathrm{C} 37}$ ratios fall on the boundary between MIS 2 and 3 and in MIS 6; the most depleted $\delta^{2} \mathrm{H}_{\mathrm{C} 37}$ ratios correspond to MIS 5, and specifically MIS 5e, the Eemian interglacial. Oxygen isotope ratios measured on the planktonic foraminifera G. bulloides for this site (de Bar et al., 2018) likewise recorded more enriched values during colder time periods and more depleted values during warmer climates (Fig. 2b). Isotope ratios for individual tri and di-unsaturated $\mathrm{C}_{37}$ alkenones were also determined (Table 1; Supp. Fig. 1). In general, both alkenones followed the same trend as the integrated $\mathrm{C}_{37}$ alkenones. Interestingly, the two diverge at the LGM, and the tri-unsaturated alkenones were more enriched in ${ }^{2} \mathrm{H}$, while the di-unsaturated alkenones became more depleted. This divergence is likely the result of a change in the relative abundance of the two alkenones. The difference in $\delta^{2} \mathrm{H}$ ratios between the two alkenones is known to be quite variable (D'Andrea et al., 2007; Schwab and Sachs, 2009; Wolhowe et al., 2009; van der Meer et al., 2013). The $\mathrm{C}_{37: 3}$ is synthesized from the $\mathrm{C}_{37: 2}$, and at colder temperatures there is a lower relative abundance of the $\mathrm{C}_{37: 2}$ (Endo et al., 2018; 
Kitamura et al., 2018). Normally, the synthesis of $\mathrm{C}_{37: 3}$ from a $\mathrm{C}_{37: 2}$ causes a depletion of the $\mathrm{C}_{37: 3}$, leaving the $\mathrm{C}_{37: 2}$ relatively enriched, since desaturation is associated with isotopic depletion (Chikaraishi et al., 2004). However, at colder temperatures, where low abundances of the $\mathrm{C}_{37: 2}$ and higher amounts of $\mathrm{C}_{37: 3}$ are expected, the synthesis of $\mathrm{C}_{37: 3}$ would become dominant and actually result in enrichment of the $\mathrm{C}_{37: 3}$ and depletion of the $\mathrm{C}_{37: 2}$ (van der Meer et al., 2013). Since most studies and salinity calibrations are based on the integrated $C_{37}$ alkenones, we focused on these for the following discussions.

$\delta^{2} \mathrm{H}_{\mathrm{C} 37}$ ratios were corrected for global ice volume using the ANICE model (de Boer et al., 2014) and the global meteoric water line (Craig and Gordon, 1965; equation 1). From these ice volume corrected $\delta^{2} \mathrm{H}_{\mathrm{C} 37}$ ratios, salinity shifts were calculated using three different equations: the surface sediment calibration of Weiss et al. (2019; equation 2), the E. huxleyi batch culture calibration (Schouten et al., 2006, equation 3), and the SPOM calibration from Gould et al. (2019; equation 4). Equation 2 yielded a substantial salinity range from 23 to 42 psu, with a value of 24 for the most modern sample (Fig. 3). Since ODP 1234 is located $\sim 70 \mathrm{~km}$ away from the coast with a water depth of $1015 \mathrm{~m}$, and salinity variations are thought to be on the order of $1-2$ psu between glacial and interglacial periods (Adkins et al., 2002; Broecker, 2002), the large range of salinity resulting from equation 2 seems unrealistic. Equation 2 most likely records mixing of alkenones from different haptophyte groups because it includes sediments from marginal marine environments with lower salinities (Weiss et al., 2019). Although these different haptophyte groups have a similar response to salinity, they each have characteristic isotope ratios, offset by $\sim 100 \%$. At the present, the Group III haptophyte E. huxleyi is the dominant alkenone-producing haptophyte off the western coast of South America (Hagino and Okada, 2004; 2006). Furthermore, analysis of calcareous nannofossils in ODP 1234 showed a dominance of E. huxleyi and a very low 
abundance of G. oceanica throughout the studied interval (Mix et al., 2003). Indeed, alkenone distributions at ODP 1234 were distinctly Group III since no isomers of tri-unsaturated

alkenones were detected, nor were any significant changes in abundance of $\mathrm{C}_{38}$ methyl alkenones observed, both of which are characteristic of Group I or II haptophytes (Longo et al., 2013; Dillon et al., 2016; Longo et al., 2016; Zheng et al., 2016). Thus, the sediment calibration of Weiss et al. (2019) is likely not applicable and it may be more logical to use a species-specific calibration to calculate paleosalinity at ODP 1234. Consequently, equation 3 for E. huxleyi from Schouten et al. (2006) was applied and reconstructed salinities varied on the order of 5 psu instead of 19 psu (Fig. 3). Using equation 3 gave a value of 32 for the most recent sample, which is in better agreement with modern measured values from the site than equation 2, although still underestimating the modern value of 33.8. Applying the Atlantic and Pacific SPOM calibration from Gould et al. (2019) (equation 4) provided an equivalent range of 6 psu (Fig. 3). The most modern sample had a salinity of 34, which aligns nicely with the modern day salinity of 33.8 (Mix et al., 2003).

Foraminiferal based proxies and climate models suggest that global ocean salinity changed on the order of $1-2$ psu between now and the Last Glacial Maximum (LGM; Adkins et al., 2002; Broecker, 2002). The $\delta^{2} \mathrm{H}_{\mathrm{C} 37}$ ratios of the Chilean Margin suggested a much larger change, regardless of the calibration used to reconstruct salinities. As outlined above, a number of environmental factors have been shown to affect $\delta^{2} \mathrm{H}_{\mathrm{C} 37}$ ratios by causing more or less fractionation between alkenones and growth water (Schouten et al., 2006; Wolhowe et al., 2009; Chivall et al., 2014; M'Boule et al., 2014; Sachs and Kawka, 2015; van der Meer et al., 2015; Sachs et al., 2016; Weiss et al., 2017), which may have contributed to the large changes in $\delta^{2} \mathrm{H}_{\mathrm{C} 37}$ ratios. These potential effects will be explored below. 


\subsection{Species and temperature effects on salinity reconstructions}

Based on alkenone distribution patterns down-core, we found only alkenones synthesized by

Group III haptophytes (i.e., $\mathrm{C}_{37: 3}, \mathrm{C}_{37: 2}$ methyl alkenones and $\mathrm{C}_{38: 3}, \mathrm{C}_{38: 2}$ ethyl and methyl alkenones). E. huxleyi is the most prevalent alkenone producing haptophyte in the modern Pacific Ocean around South America (Hagino and Okada, 2004, 2006). Nonetheless, as explained above, it is possible that fluctuations in dominant Group III alkenone producers $E$. huxleyi and G. oceanica occurred over the last $150 \mathrm{kyr}$, although nannofossil data for ODP 1234 showed a dominance of E. huxleyi and very sparse presence of G. oceanica throughout the last $150 \mathrm{kyr}$ (Mix et al., 2003). Although the differences in the slopes for the $\delta^{2} \mathrm{H}_{\mathrm{C} 37}-$ salinity equation between E. huxleyi and G. oceanica are not substantial (4.8 versus 4.2 respectively, Schouten et al., 2006), G. oceanica fractionates hydrogen to a larger extent than E. huxleyi. Thus, if changes in the main alkenone producer took place in the past, additional shifts in $\delta^{2} \mathrm{H}_{\mathrm{C} 37}$, on top of those caused by salinity changes, could occur. G. oceanica is thought to be the principal alkenone producer in warm, high salinity marginal seas, while $E$. huxleyi is more dominant in open ocean settings (Okada and Honjo, 1975). It might have been the case that G. oceanica became the major contributor of alkenones into the sedimentary record during warmer time periods, and E. huxleyi supplied the majority of alkenones in colder climates. Furthermore, it has been suggested that temperature itself can affect the $\delta^{2} \mathrm{H}_{\mathrm{C} 37}$ (Wolhowe et al., 2009). However, compiled results of temperature experiments with E. huxleyi and G. oceanica showed an insignificant negative correlation between $\delta^{2} \mathrm{H}_{\mathrm{C} 37}$ and temperature $(\mathrm{r}=-0.43, \mathrm{p}>0.05$; data from Schouten et al., 2006 and Wolhowe et al., 2009). In addition, analyses of SPM in the Pacific Ocean over a temperature change of $1-4{ }^{\circ} \mathrm{C}$, showed no systematic changes in $\delta^{2} \mathrm{H}_{\mathrm{C} 37}$ ratios or in alkenone producers (Wolfshorndl et al., 2019), suggesting that the potential effect of temperature on either relative abundance of alkenone producers or $\delta^{2} \mathrm{H}_{\mathrm{C} 37}$ ratios hypothesized from culture studies 
might not actually exist in the natural environment. $\mathrm{U}^{\mathrm{k}^{\prime}}{ }_{37}$ ratios from ODP 1234 suggested a temperature change of $3{ }^{\circ} \mathrm{C}$ between the LGM and the most modern sample (de Bar et al., 2018), similar to the range of temperature observed in the Pacific Ocean study (Wolfshorndl et al., 2019). Thus, by extrapolating these results to our dataset, we concluded that the temperature shifts between the LGM and the modern are not large enough to cause substantial shifts in relative abundance of alkenone producers, nor should these temperature changes have had a significant effect on $\delta^{2} \mathrm{H}_{\mathrm{C} 37}$ ratios.

\subsection{Nutrients and light}

Algal growth rate is regulated by nutrient availability and light intensity. Both parameters caused changes in fractionation in batch and continuous culture experiments of different haptophyte species (Sachs and Kawka, 2015; van der Meer et al., 2015). Growth rate negatively correlated with fractionation factor $\alpha_{\mathrm{C} 37}$, meaning faster growth led to increased fractionation (Schouten et al., 2006; Sachs and Kawka, 2015). Light intensity caused significant variation in $\alpha_{\mathrm{C} 37}$ at irradiance levels below $\sim 200 \mu \mathrm{mol}$ photons $\mathrm{m}^{-2} \mathrm{~s}^{-1}$, but above $200 \mu \mathrm{mol}$ photons $\mathrm{m}^{-2} \mathrm{~s}^{-1}$ there was a negligible effect of light on fractionation (van der Meer et al., 2015). A field comparison between light-limited and nutrient-limited sites in the Pacific Ocean suggested that environmental variation in $\delta^{2} \mathrm{H}$ ratios under different irradiance and nutrient regimes was smaller than observed in laboratory culture, and therefore may not be of significant concern for paleo studies (Wolfshorndl et al., 2019). Since the sediment samples used here encompass numerous years and growth seasons, we could not actually correct for these parameters nor constrain them on a per event basis. Furthermore, the effects of irradiance and nutrient concentration were hypothesized to be negligible in the field (Wolfshorndl et al., 2019), leading to the assumption that they did not significantly contribute to the variation in the $\delta^{2} \mathrm{H}_{\mathrm{C} 37}$ ratios at ODP 1234 . 


\subsection{Influences of water isotope ratios}

Mixing of different water masses has the potential to cause variation in $\delta^{2} \mathrm{H}_{\mathrm{H} 2 \mathrm{O}}$ and therefore, $\delta^{2} \mathrm{H}_{\mathrm{C} 37}$ ratios. Antarctic waters are colder and isotopically lighter than water in the tropics (Lee et al., 2007). A strengthening of the ACC during glacial periods has been hypothesized (Pudsey and Howe, 1998; Barker and Thomas, 2004) and thus shifts in $\delta^{2} \mathrm{H}_{\mathrm{C} 37}$ ratios could correspond to more input of these colder and relatively depleted waters via the ACC during glacials. However, the observed shifts in $\delta^{2} \mathrm{H}_{\mathrm{C} 37}$ ratios were not large enough to be attributed to ACC as the dominant water mass during glacial periods because influence of isotopically lighter and lower salinity waters would cause a substantially depleted $\delta^{2} \mathrm{H}_{\mathrm{C} 37}$ signal, similar to values noted for off-shore Colombia below -205 \%o (Pahnke et al., 2007). For the same reason, we can also exclude the influence of large volumes of river runoff, which are similarly characterized by a significantly depleted $\delta^{2} \mathrm{H}_{\mathrm{C} 37}$ signal. Such depleted values were not observed at ODP 1234, leading to the conclusion that neither the ACC nor substantial continental runoff could be evidenced in the $\delta^{2} \mathrm{H}_{\mathrm{C} 37}$ ratios at ODP 1234 during the last $\sim 150$ kyr.

Past $\delta^{2} \mathrm{H}$ water isotope ratios were calculated from oxygen isotope ratios, either from models or other proxy data, using the meteoric water line (equation 1), and used to correct for the impact of global ice volume changes. In a highly evaporative basin, such as the Mediterranean, the local meteoric water line has higher $d$ excess, but the slope is the same as the global meteoric water line (Gat, 1980, 1982; Gat and Carmi, 1987). For the majority of the surface ocean, it is hypothesized that $d$ excess is near zero and only reaches as high as six in highly evaporative regions (Rohling, 2007). Thus, potential differences in the $\delta^{18} \mathrm{O}$ and $\delta^{2} \mathrm{H}$ correlation in the surface ocean are not large enough to cause significant changes to the ice volume correction, and therefore would not substantially alter our paleosalinity reconstructions. 
Thus, at this point the seemingly higher sensitivity of $\delta^{2} \mathrm{H}_{\mathrm{C} 37}$ to paleosalinity changes compared to present day sensitivity in cultures and the natural environment cannot be explained by any of the parameters that have been shown to affect this sensitivity in culture or environmental datasets. For this reason, we conclude that the $\delta^{2} \mathrm{H}_{\mathrm{C} 37}$ ratios at ODP 1234 were primarily reflecting changes in sea surface salinity, and these changes may either be larger than previously hypothesized (Adkins et al., 2002; Broecker, 2002), or reflect a greater sensitivity of $\delta^{2} \mathrm{H}_{\mathrm{C} 37}$ to salinity.

\subsection{Comparison with previous records}

Paleosalinity estimates based on $\delta^{18} \mathrm{O}$ ratios of the foraminifera Neogloboquadrina pachyderma (corrected for temperature using $\mathrm{U}^{\mathrm{K}^{\prime}}{ }_{37}$ temperature estimates) over the last $8 \mathrm{kyr}$ at a nearby site showed a change from 33 - 36 psu over this short time period (Lamy et al., 2002) suggesting that this region might have larger fluctuations in salinity than the global average. While $\delta^{2} \mathrm{H}_{\mathrm{C} 37}$ ratios suggest larger salinity shifts over longer time periods, both the Schouten et al. (2006) and Gould et al. (2019) calibrations suggest a salinity change of $\sim 2$ psu over the last 9 kyr. Estimates based on foraminiferal $\delta^{18} \mathrm{O}$ ratios combined with $\mathrm{U}^{\mathrm{K}}{ }_{37}$ temperatures are subject to large uncertainties (Rohling, 2007), and might be biased by differences between these two proxies. Thus, to investigate whether the higher paleosensitivity of $\delta^{2} \mathrm{H}_{\mathrm{C} 37}$ to salinity at ODP site 1234 was also observed elsewhere, or is unique to the Chilean Margin, we examined other previously published $\delta^{2} \mathrm{H}_{\mathrm{C} 37}$ records. For this exercise, we considered the difference in $\delta^{2} \mathrm{H}_{\mathrm{C} 37}$ between the most modern value and that of the LGM at 21 ka. We included records from off-shore Colombia (Pahnke et al., 2007), the Agulhas leakage (Kasper et al., 2014), Benguela Upwelling (Petrick et al., 2015), and the Indian-Atlantic Ocean Gateway (Simon et al., 2015). The Mozambique Channel (Kasper et al., 2015) and Gulf of Guinea (Leduc et al., 2013) records were excluded from this exercise. The Mozambique Channel record does not record a depletion from the LGM to the modern, 
as a result of lower sea levels and higher freshwater influx during the LGM at the core location (values are included in Table 2). At the Mozambique Channel site, Kasper et al. (2015) proposed that mixing of alkenones from coastal and marine producers caused a dampening of the $\delta^{2} \mathrm{H}_{\mathrm{C} 37}$ signal at this location. The Gulf of Guinea record only covers the Holocene, and therefore was also excluded from this exercise. The general trends in all previously published records matched well with each other (e.g. more enriched $\delta^{2} \mathrm{H}_{\mathrm{C} 37}$ ratios for the LGM than for the most modern sediment), but the amplitude of the shifts and the absolute values were different for each location due to regional climate characteristics (Fig. 4). To estimate sensitivity, the difference between LGM and the modern was divided by two psu (Table 2), assuming that this is the general salinity difference between modern and LGM (Adkins et al., 2002; Broecker, 2002). The sensitivity from these records ranged from 4.5 to 9 $\%$ per psu, with a value of 5.5 for ODP 1234 . A sensitivity of $9 \%$ per psu is unprecedented in any environmental or laboratory culture investigation of $\delta^{2} \mathrm{H}_{\mathrm{C} 37}$ ratios, and the closest, the E. huxleyi calibration of Schouten et al. (2006), is half of that. It holds, then, that either something is missing from our understanding of paleo $\delta^{2} \mathrm{H}_{\mathrm{C} 37}$ ratios, or salinity shifts were actually larger than other proxies suggested by about a factor of 2. Further research employing multiproxy approaches using inorganic proxies like $\mathrm{Na} / \mathrm{Ca}$ or paired $\delta^{18} \mathrm{O}$ and $\mathrm{Mg} / \mathrm{Ca}$ in conjunction with $\delta^{2} \mathrm{H}_{\mathrm{C} 37}$ ratios may shed light on this enigma.

\section{Conclusions}

$\delta^{2} \mathrm{H}_{\mathrm{C} 37}$ ratios for the last $150 \mathrm{kyr}$ recorded global climate trends on glacial to interglacial timescales at ODP site 1234. Application of different calibrations for the $\delta^{2} \mathrm{H}_{\mathrm{C} 37}$ - salinity relationship resulted in extremely large shifts in salinity that are unprecedented in open ocean sites based on present understanding of sea surface salinity. A larger slope for the $\delta^{2} \mathrm{H}_{\mathrm{C} 37}-$ salinity relationship has to be invoked in order to reconstruct paleosalinities with changes of 1 -2 psu between glacial and interglacial time periods. Based on other sediment records of 
$\delta^{2} \mathrm{H}_{\mathrm{C} 37}$ ratios, a paleosensitivity between 4.5 and 9 provided estimates of relative changes in salinity for open ocean sites that align with current knowledge of glacial and interglacial global salinity shifts inferred from oxygen isotope based proxies and climate models.

However, such a large slope has not previously been recorded in laboratory culture or natural environmental settings. This suggests that either our understanding of the salinity response to $\delta^{2} \mathrm{H}_{\mathrm{C} 37}$ ratios is incomplete, or salinity shifts were actually larger than previously suggested.

\section{Acknowledgments, Samples, and Data}

The authors would like to thank Phil Rumford for ODP 1234 core sampling. We would also like to thank Editor in Chief Dr. Ellen Thomas, Associate Editor Dr. Gabriel Bowen, Dr.

Daniel Nelson, and one anonymous reviewer for their input which greatly improved this manuscript. This study received funding from the Netherlands Earth System Science Center (NESSC) though a Gravitation grant (024.002.001) from the Dutch Ministry for Education,

Culture and Science. All acquired data is stored in the Pangaea database (doi: 10.1594/PANGAEA.900871).

\section{References}

Adkins, J. F., McIntyre, K., \& Schrag, D. P. (2002). The salinity, temperature, and $\delta^{18} \mathrm{O}$ of the glacial deep ocean. Science, 298, 1769-1773.

Bakun, A. (1990). Global climate change and intensification of coastal ocean upwelling. Science, 247(4939), 198-201.

Barker, P. F., \& Thomas, E. (2004). Origin, signature and palaeoclimatic influence of the Antarctic Circumpolar Current. Earth-Science Reviews, 66(1-2), 143-162.

Brassell, S.C., Eglinton, G., Marlowe, I.T., Pflaumann, U., \& Sarnthein, M. (1986), Molecular stratigraphy: a new tool for climatic assessment. Nature, 320, 129-133.

Broecker, W.S. (2002), The glacial world according to Wally. Lamont-Doherty earth observatory of Columbia University., Palisades, NY. 318.

Busch, W. H., \& Keller, G. H. (1981), The physical properties of Peru-Chile continental margin sediments; the influence of coastal upwelling on sediment properties. Journal of Sedimentary Research, 51(3), 705-719. 
Chikaraishi, Y., Suzuki, Y., \& Naraoka, H. (2004), Hydrogen isotopic fractionations during desaturation and elongation associated with polyunsaturated fatty acid biosynthesis in marine macroalgae. Phytochemistry, 65, 2293-2300.

Chivall, D., M'Boule, D., Sinke-Schoen, D., Sinninghe Damsté, J.S., Schouten, S., \& van der Meer, M.T.J. (2014). The effects of growth phase and salinity on the hydrogen isotopic composition of alkenones produced by coastal haptophyte algae. Geochimica et Cosmochimica Acta, 140, 381-390.

Craig, H. \& Gordon, L.I. (1965). Deuterium and oxygen 18 variations in the ocean and the marine atmosphere, in: Stable Isotopes in Oceanographic Studies and Paleotemperatures, Spoleto, 9-130.

D’Andrea, W.J., Liu, Z., Da Rosa Alexandre, M., Wattley, S., Herbert, T.D., \& Huang, Y. (2007). An efficient method for isolating individual long-chain alkenones for compoundspecific hydrogen isotope analysis. Analytical Chemistry, 79, 3430-3435.

de Bar, M.W., Stolwijk, D.J., McManus, J.F., Sinninghe Damsté, J.S., \& Schouten, S. (2018). A Late Quaternary climate record based on long chain diol proxies from the Chilean margin. Climate of the Past, 14, 1783 - 1803.

de Boer, B., Stocchi, P., \& Van De Wal, R. (2014). A fully coupled 3-D ice-sheet-sea-level model: algorithm and applications. Geoscientific Model Development, 7(5), 2141-2156.

de Leeuw, J.W., van der Meer, F.W., Rijpstra, W.I.C., \& Schenck, P.A. (1980). On the occurrence and structural identification of long chain unsaturated ketones and hydrocarbons in sediments. In: Advances in Organic Geochemistry 1979 (Eds. A.G. Douglas, J.R. Maxwell), Pergamon Press, Oxford, 211-217.

Dillon, J. T., Longo, W. M., Zhang, Y., Torozo, R., \& Huang, Y. (2016). Identification of double- bond positions in isomeric alkenones from a lacustrine haptophyte. Rapid Communications in Mass Spectrometry, 30(1), https://doi.org.proxy.library.uu.nl/10.1002/rcm.7414.

Dugdale, R. C., Goering, J. J., Barber, R. T., Smith, R. L., \& Packard, T. T. (1977). Denitrification and hydrogen sulfide in the Peru upwelling region during 1976. Deep Sea Research, 24(6), 601-608.

Duplessy, J. C., Labeyrie, L., Juilletleclerc, A., Maitre, F., Duprat, J., \& Sarnthein, M. (1991). Surface salinity reconstruction of the North-Atlantic ocean during the last glacial maximum. Oceanologica Acta, 14, 311-324.

Elderfield, H. \& Ganssen, G. (2000). Past temperature and $\delta^{18} \mathrm{O}$ of surface ocean waters inferred from foraminiferal $\mathrm{Mg} / \mathrm{Ca}$ ratios. Nature, 405, 442-445.

Emiliani, C. (1955) Pleistocene Temperatures. Journal of Geology, 63, 538-578.

Endo, H., Yutaka, H., Horiya, A., Iwane, S., \& Yoshinihiro, S. (2018). Overexpression of Tisochrysis lutea Akd1 identifies a key cold-induced alkenone desaturase enzyme. Scientific Reports, 8, 11230. 
Gat, J.R., (1980). The isotopes of hydrogen and oxygen in precipitation. In: Fritz, P., Fontes, G. (Eds.), Handbook of Environmental Isotope Geochemistry, Vol. 1. Elsevier, Amsterdam, 21-47.

Gat, J.R. (1982). Precipitation, groundwater and surface waters. Paleoclimates and Paleowaters. International Atomica Energy Agency, Vienna, 3-12.

Gat, J.R., \& Carmi, I. (1987). Effect of climate changes on the precipitation patterns and isotopic composition of water in a climate transition zone: case of the Mediterranean Sea area. The Influence of Climate Change and Climatic Variability on the Hydrological Regime and Water Resources. Proceedings of the Vancouver Symposium, IAHS Publ. No. 168, August 1987, 513-523.

Gould, J., Kienast, M., Dowd, M., \& Shefuß, E. (2019). An open-ocean assessment of alkenone $\delta \mathrm{D}$ as a paleo-salinity proxy. Geochimica et Cosmochimica Acta, 246, 478-497.

Hagino, K., \& Okada, H. (2004). Floral response of coccolithophores to progressive oligotrophication in the South Equatorial Current, Pacific Ocean. Global Environmental Change in the Ocean and on Land. Terrapub: Tokyo, 121-132.

Hagino, K., \& Okada, H. (2006). Intra-and infra-specific morphological variation in selected coccolithophore species in the equatorial and subequatorial Pacific Ocean. Marine Micropaleontology, 58(3), 184-206.

Heusser, L., Heusser, C., Mix, A., \& McManus, J.F. (2006). Chilean and southeast Pacific paleoclimate variations during the last glacial cycle: directly correlated pollen and $\delta^{18} \mathrm{O}$ records from ODP site 1234. Quaternary Science Reviews, 25, 3404-3415.

Kasper, S., van der Meer, M.T.J., Mets, A., Zahn, R., Sinninghe Damsté, J.S., \& Schouten, S. (2014). Salinity changes in the Agulhas leakage area recorded by stable hydrogen isotopes of $\mathrm{C}_{37}$ alkenones during Termination I and II. Climate of the Past, 10, 251-260.

Kasper, S., van der Meer, M.T.J., Castañeda, I.S., Tjallingii, R., Brummer, G.J.A., Sinninghe Damsté, J.S., \& Schouten, S. (2015). Testing the alkenone D/H ratio as a paleo indicator of sea surface salinity in a coastal ocean margin (Mozambique Channel). Organic Geochemistry, 78, 62-68.

Kitamura, E., Kotajima, T., Sawada, K., Suzuki, I., \& Shiraiwa, Y. (2018). Cold-induced metabolic conversion of haptophyte di- to triunsaturated $\mathrm{C}_{37}$-alkenones used as paleothermometer molecules. Scientific Reports 8, 2196.

Lamy, F., Rühlemann, C., Hebbeln, D., \& Wefer, G. (2002). High-and low-latitude climate control on the position of the southern Peru-Chile Current during the Holocene. Paleoceanography, 17.

Leduc, G., Sachs, J.P., Kawka, O.E., \& Schneider, R.R. (2013). Holocene changes in eastern equatorial Atlantic salinity as estimated by water isotopologues. Earth and Planetary Science Letters, 362, 151-162. 
Lee, J. E., Fung, I., DePaolo, D. J., \& Henning, C. C. (2007). Analysis of the global distribution of water isotopes using the NCAR atmospheric general circulation model. Journal of Geophysical Research: Atmospheres, 112.

Lisiecki, L. E. \& Raymo, M. E. (2005). A Pliocene- Pleistocene stack of 57 globally distributed benthic $\delta 180$ records. Paleoceanography, 20 .

Longo, W. M., Dillon, J. T., Tarozo, R., Salacup, J. M., \& Huang, Y. (2013). Unprecedented separation of long chain alkenones from gas chromatography with a poly (trifluoropropylmethylsiloxane) stationary phase. Organic Geochemistry, 65, 94-102.

Longo, W. M., Theroux, S., Giblin, A. E., Zheng, Y., Dillon, J. T., \& Huang, Y. (2016). Temperature calibration and phylogenetically distinct distributions for freshwater alkenones: evidence from northern Alaskan lakes. Geochimica et Cosmochimica Acta, 180, 177-196.

Marchant, M., Hebbeln, D., \& Wefer, G. (1999). High resolution planktic foraminiferal record of the last 13,300 years from the upwelling area off Chile. Marine Geology, 161(2-4), 115-128.

Marlowe, I.T., Green, J.C., Neal, A.C., Brassell, S.C., Eglinton, G., \& Course, P.A. (1984). Long chain (n-C37-C39) alkenones in the Prymnesiophyceae. Distribution of alkenones and other lipids and their taxonomic significance. British Phycological Journal, 19, 203-216.

M'Boule, D., Chivall, D., Sinke-Schoen, D., Sinninghe Damsté, J.S., Schouten, S., \& van der Meer, M.T.J. (2014). Salinity dependent hydrogen isotope fractionation in alkenones produced by coastal and open ocean haptophyte algae. Geochimica et Cosmochimica Acta, $130,126-135$.

Mezger, E.M., de Nooijer, L.J., Siccha, M., Brummer, G.J.A., Kucera, M., \& Reichart, G.J. (2018). Taphonomic and ontogenetic effects on $\mathrm{Na} / \mathrm{Ca}$ and $\mathrm{Mg} / \mathrm{Ca}$ in spinose planktonic foraminifera from the Red Sea. Geochemistry, Geophysics, Geosystems, 19, 4174-4194.

Mix, A.C., Tiedemann, R., Blum, P., et al. (2003). Proceedings of the Ocean Drilling Program, Initial Reports, 202: College Station, TX (Ocean Drilling Program). doi:10.2973/odp.proc.ir.202.2003

Muratli, J. M., Chase, Z., McManus, J. F., \& Mix, A. (2010). Ice-sheet control of continental erosion in central and southern Chile $\left(36^{\circ}-41^{\circ} \mathrm{S}\right)$ over the last 30,000 years, Quaternary Science Reviews, 29, 3230-3239.

Nelson, D. B., \& SACHS, J. P. (2014). THE INFLUENCE OF SALINITY ON D/H FRACTIONATION IN ALKENONES FROM SALINE AND HYPERSALINE LAKES IN CONTINENTAL NORTH AMERICA. Organic Geochemistry, 66, 38-47.

Okada, H., \& Honjo, S. (1975). Distribution of coccolithophores in marginal seas along the western Pacific Ocean and in the Red Sea. Marine Biology, 31(3), 271-285.

Pahnke, K., Sachs, J. P., Keigwin, L., Timmermann, A., \& Xie, S. P. (2007). Eastern tropical Pacific hydrologic changes during the past 27,000 years from $\mathrm{D} / \mathrm{H}$ ratios in alkenones. Paleoceanography, 22(4). 
Petrick, B. F., McClymont, E. L., Marret, F., \& Meer, M. T. (2015). Changing surface water conditions for the last $500 \mathrm{ka}$ in the Southeast Atlantic: implications for variable influences of Agulhas leakage and Benguela upwelling. Paleoceanography, 30, 1153-1167.

Prahl, F. G., \& Wakeham, S. G. (1987). Calibration of unsaturation patterns in long-chain ketone compositions for palaeotemperature assessment. Nature, 330(6146), 367.

Pudsey, C. J., \& Howe, J. A. (1998). Quaternary history of the Antarctic Circumpolar Current: evidence from the Scotia Sea. Marine Geology, 148(1-2), 83-112.

Rahmstorf, S. (2002). Ocean circulation and climate during the past 120,000 years. Nature, 419, 207-217.

Rohling, E.J. (2007). Progress in paleosalinity: overview and presentation of a new approach. Paleoceanography, 22.

Sachs, J.P. \& Kawka, O.E. (2015). The influence of growth rate on ${ }^{2} \mathrm{H} /{ }^{1} \mathrm{H}$ fractionation in continuous cultures of the coccolithophorid Emiliania huxleyi and the diatom Thalassiosira pseudonana. PLoS ONE, 10, https://doi.org/10.1371/journal.pone.0141643.

Sachs, J.P., Maloney, A.P., Gregersen, J., \& Paschall, C. (2016). Effect of salinity on ${ }^{2} \mathrm{H} /{ }^{1} \mathrm{H}$ fractionation in lipids from continuous cultures of the coccolithophorid Emiliania huxleyi. Geochimica et Cosmochimica Acta, 189, 96-109.

Schouten, S. Hopmans, E.D., Shefuß, E. \& Sinninghe Damsté, J.S. (2002). Distributional variations in marine chrenarchaeotal membrane lipids: a new tool for reconstructing ancient sea water temperature? Earth and Planetary Science Letters, 204, 265-274.

Schouten S., Ossebar, J., Shreiber, K., Kienhuis, M.V.M., Benthien, A., \& Bijma, J. (2006). The effect of temperature, salinity and growth rate on the stable hydrogen isotopic composition of long chain alkenones produced by Emiliania huxleyi and Gephyrocapsa oceanica. Biogeosciences, 3, 113-119.

Schwab, V.F., \& Sachs, J.P. (2009). The measurement of D/H ratio in alkenones and their isotopic heterogeneity. Organic Geochemistry, 40, 111-118.

Schwab, V.F., \& Sachs, J.P. (2011). Hydrogen isotopes in individual alkenones from the Chesapeake Bay estuary. Geochimica et Cosmochimica Acta, 75, 7552-7565.

Shackleton, N.J. (1987). Oxygen isotopes, ice volume and sea level. Quaternary Science Reviews, 6, $183-190$.

Simon, M.H., Gong, X., Hall, I.R., Ziegler, M., Barker, S., Knorr, G., et al. (2015). Salt exchange in the Indian Atlantic Ocean Gateway since the Last Glacial Maximum: A compensating effect between Agulhas Current changes and salinity variations? Paleoceanography, 30, 1318-1327. 
Strub, P.T., Mesias, J.M., Montecino, V., Rutllant, J., \& Salinas, S. (1998). Coastal ocean circulation off western South America. In Robinson, A.R., and Brink, K.H. (Eds.), The Sea (Vol. 11): Coastal Oceans: New York (Wiley), 273-313.

Theroux, S., D'Andrea, W. J., Toney, J., Amaral-Zettler, L., \& Huang, Y. (2010).

Phylogenetic diversity and evolutionary relatedness of alkenone-producing haptophyte algae in lakes: implications for continental paleotemperature reconstructions. Earth and Planetary Science Letters, 300(3-4), 311-320.

van der Meer, M.T., Baas, M., Rijpstra, W.I.C., Marino, G., Rohling, E.J., Sinninghe Damsté, J.S. \&Schouten, S. (2007). Hydrogen isotopic compositions of long-chain alkenones record freshwater flooding of the Eastern Mediterranean at the onset of sapropel deposition. Earth and Planetary Science Letters, 262, 594-600.

van der Meer, M. T., Sangiorgi, F., Baas, M., Brinkhuis, H., Sinninghe Damsté, J. S., \& Schouten, S. (2008). Molecular isotopic and dinoflagellate evidence for Late Holocene freshening of the Black Sea. Earth and Planetary Science Letters, 267(3-4), 426-434.

van der Meer, M.T.J., Benthien, A., Bijma, J., Schouten S., \& Sinninghe Damsté, J.S. (2013). Alkenone distribution impacts the hydrogen isotopic composition of the $\mathrm{C}_{37: 2}$ and $\mathrm{C}_{37: 2}$ alkan2-ones in Emiliania huxleyi. Geochimica et Cosmochimica Acta, 111, 162-166.

van der Meer, M.T.J., Benthien, A., French, K.L., Epping, E., Zondervan, I., Reichart, G.J., et al. (2015). Large effect of irradiance on hydrogen isotope fractionation of alkenones in Emiliania huxleyi. Geochimica et Cosmochimica Acta, 160, 16-24.

Vargas, G., Pantoja, S., Rutllant, J. A., Lange, C. B., \& Ortlieb, L. (2007). Enhancement of coastal upwelling and interdecadal ENSO-like variability in the Peru-Chile Current since late 19th century. Geophysical Research Letters, 34(13).

Vasiliev, I., Reichart, G. J., \& Krijgsman, W. (2013). Impact of the Messinian Salinity Crisis on Black Sea hydrology-Insights from hydrogen isotopes analysis on biomarkers. Earth and Planetary Science Letters, 362, 272-282.

Volkman, J.K., Eglinton, G., Corner, E.D.S., \& Sargent, J.R. (1980). Novel unsaturated straight-chain $\mathrm{C}_{37}-\mathrm{C}_{39}$ methyl and ethyl ketones in marine sediments and a coccolithophore Emiliania huxleyi. Physics and Chemistry of the Earth, 12, 219-227.

Weiss, G.M., Pfannerstill, E.Y., Schouten, S., Sinninghe Damsté, J.S., \& van der Meer, M.T.J. (2017). Effects of alkalinity and salinity at low and high light intensity on hydrogen isotope fractionation of long-chain alkenones produced by Emiliania huxleyi. Biogeosciences, $14,5693-5704$.

Weiss, G.M., Schouten, S., Sinninghe Damsté, J.S., \& van der Meer, M.T.J. (2019). Constraining the application of hydrogen isotopic composition of alkenones as a salinity proxy using marine surface sediments. Geochimica et Cosmochimica Acta, 250, 34-48.

Weldeab, S., D. W. Lea, R. R. Schneider, \& Andersen, N. (2007). 155,000 years of West African monsoon and ocean thermal evolution. Science, 316, 1303-1307. 
Wit, J. C., de Nooijer, L. J., Wolthers, M., \& Reichart, G. J. (2013). A novel salinity proxy based on Na incorporation into foraminiferal calcite. Biogeosciences, 10, 6375-6387, https://doi.org/10.5194/bg-10-6375-2013.

Wolfshorndl, M., Danford, R., \& Sachs, J.P. (2019). ${ }^{2} \mathrm{H} /{ }^{1} \mathrm{H}$ fractionation in microalgal lipids from the North Pacific Ocean: Growth rate and irradiance effects. Geochimica et Cosmochimica Acta, 246, 317-338.

Wolhowe, M.D., Prahl, F.G., Probert, I., \& Maldonado, M. (2009). Growth phase dependent hydrogen isotopic fractionation in alkenone-producing haptophytes. Biogeosciences, 6, 16811694.

Wolhowe, M.D., Prahl, F.G., Langer, G., Oviedo, A.M., \& Ziveri, P. (2015). Alkenone $\delta D$ as an ecological indicator: A culture and field study of physiologically-controlled chemical and hydrogen isotopic variation in $\mathrm{C}_{37}$ alkenones. Geochimica et Cosmochimica Acta, 162, 166-182.

Zheng, Y., Dillon, J. T., Zhang, Y., \& Huang, Y. (2016). Discovery of alkenones with variable methylene-interrupted double bonds: implications for the biosynthetic pathway. Journal of Phycology, 52(6), 1037-1050.

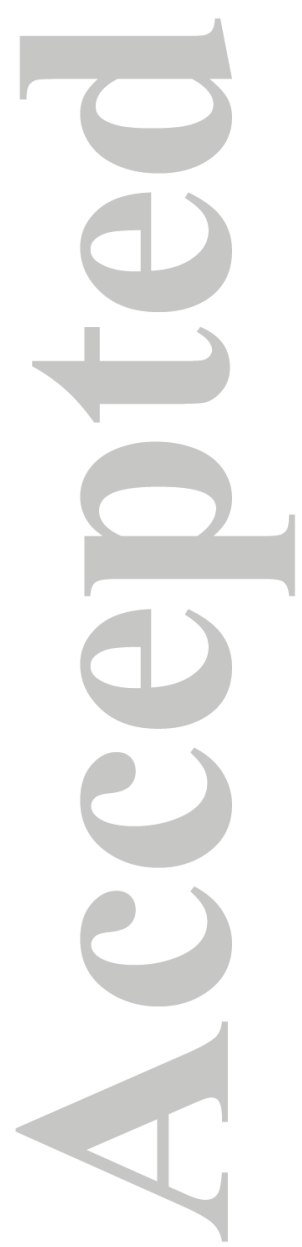


Table 1. Hydrogen isotope ratios of long-chain alkenones (both individual $\mathrm{C}_{37: 3}$ and $\mathrm{C}_{37: 2}$ as well as integrated $\mathrm{C}_{37}$ alkenones) measured on sediment extracts from ODP 1234 over the last $\sim 150 \mathrm{kyr}$.

\begin{tabular}{|c|c|c|c|c|c|c|c|c|c|}
\hline Age (kyr) & Depth $(\mathrm{mcd})$ & $\begin{array}{c}\mathrm{C}_{37} \text { Alkenone } \\
\text { Concentration } \\
(\mu \mathrm{g} / \mathrm{g} \\
\text { sediment }) \\
\end{array}$ & $\begin{array}{c}\delta^{2} \mathrm{H}_{\mathrm{C} 37: 3}(\% \% \\
\text { vs VSMOW }) \\
\end{array}$ & S.D. & $\begin{array}{c}\delta^{2} \mathrm{H}_{\mathrm{C} 372.2}(\% \\
\text { vs VSMOW }) \\
\end{array}$ & S.D. & $\begin{array}{c}\delta^{2} \mathrm{H}_{\mathrm{C} 37}(\% \text { vs } \\
\text { VSMOW) } \\
\end{array}$ & S.D. & $\begin{array}{c}\text { Ice volume } \\
\text { corrected } \\
\delta^{2} \mathrm{H}_{\mathrm{C} 37} \\
\end{array}$ \\
\hline 1.0 & 0.1 & 4.63 & -191 & 0 & -199 & 0 & -195 & 0 & -195 \\
\hline 5.3 & 1.1 & 2.07 & -189 & 0 & -198 & 1 & -193 & 0 & -194 \\
\hline 9.1 & 2.2 & 1.89 & -183 & 0 & -188 & 0 & -185 & 0 & -186 \\
\hline 10.8 & 2.8 & 1.44 & -179 & 2 & -183 & 2 & -181 & 2 & -183 \\
\hline 13.1 & 3.6 & 1.87 & -175 & 1 & -176 & 2 & -175 & 1 & -178 \\
\hline 15.0 & 4.4 & 1.73 & -174 & 2 & -177 & 2 & -176 & 2 & -182 \\
\hline 17.0 & 5.3 & 1.00 & -173 & 2 & -176 & 4 & -174 & 1 & -182 \\
\hline 19.3 & 6.5 & 1.07 & -172 & 1 & -180 & 1 & -176 & 0 & -183 \\
\hline 20.1 & 7.0 & 1.67 & -170 & 1 & -181 & 1 & -176 & 1 & -183 \\
\hline 21.4 & 7.8 & 1.69 & -172 & 2 & -184 & 2 & -177 & 2 & -184 \\
\hline 24.0 & 9.6 & 1.51 & -173 & 1 & -180 & 2 & -175 & 2 & -182 \\
\hline 26.8 & 11.8 & 1.43 & -176 & 0 & -177 & 1 & -176 & 1 & -182 \\
\hline 27.8 & 12.7 & 0.45 & -173 & 2 & -178 & 3 & -175 & 2 & -181 \\
\hline 29.2 & 13.9 & 1.64 & -172 & 1 & -177 & 0 & -173 & 1 & -179 \\
\hline 30.5 & 15.1 & 2.07 & -166 & 1 & -167 & 2 & -167 & 2 & -172 \\
\hline 32.9 & 17.2 & 1.14 & -177 & 1 & -180 & 0 & -178 & 1 & -183 \\
\hline 35.3 & 19.2 & 1.48 & -177 & 1 & -182 & 3 & -179 & 2 & -184 \\
\hline 37.6 & 21.1 & 1.82 & -177 & 2 & -176 & 3 & -177 & 2 & -182 \\
\hline 39.7 & 22.7 & 2.29 & -179 & 1 & -179 & 1 & -178 & 2 & -183 \\
\hline 41.8 & 24.3 & 1.63 & -183 & 4 & -187 & 3 & -185 & 4 & -190 \\
\hline
\end{tabular}




\begin{tabular}{|c|c|c|c|c|c|c|c|c|c|}
\hline 43.9 & 25.9 & 1.45 & -184 & 2 & -181 & 2 & -183 & 2 & -188 \\
\hline 46.3 & 27.8 & 1.99 & -181 & 1 & -183 & 1 & -181 & 1 & -185 \\
\hline 47.9 & 29.1 & 1.60 & -178 & 2 & -177 & 2 & -177 & 2 & -182 \\
\hline 49.9 & 30.7 & 1.79 & -179 & 1 & -181 & 0 & -179 & 1 & -184 \\
\hline 51.9 & 32.4 & 1.69 & -184 & 1 & -183 & 1 & -185 & 1 & -189 \\
\hline 53.7 & 34.0 & 2.71 & -181 & 0 & -181 & 0 & -181 & 0 & -186 \\
\hline 55.4 & 35.6 & 1.84 & -186 & 1 & -188 & 1 & -187 & 1 & -192 \\
\hline 58.4 & 38.8 & 2.21 & -188 & 2 & -192 & 3 & -190 & 2 & -194 \\
\hline 60.5 & 41.1 & 2.12 & -178 & 2 & -181 & 3 & -180 & 2 & -184 \\
\hline 62.3 & 43.2 & 1.77 & -185 & 1 & -184 & 2 & -184 & 1 & -189 \\
\hline 63.6 & 45.7 & 1.61 & -179 & 1 & -177 & 0 & -178 & 1 & -182 \\
\hline 65.6 & 48.3 & 2.16 & -182 & 2 & -181 & 2 & -183 & 2 & -187 \\
\hline 67.5 & 50.6 & 2.62 & -182 & 1 & -190 & 2 & -185 & 2 & -189 \\
\hline 72.7 & 54.8 & 4.00 & -192 & 3 & -197 & 5 & -194 & 3 & -197 \\
\hline 75.4 & 56.4 & 5.92 & -188 & 1 & -198 & 5 & -191 & 2 & -194 \\
\hline 78.8 & 58.0 & 5.36 & -187 & 2 & -192 & 0 & -189 & 1 & -192 \\
\hline 82.3 & 59.6 & 6.15 & -189 & 1 & -197 & 0 & -193 & 2 & -195 \\
\hline 85.6 & 61.4 & 3.00 & -187 & 2 & -191 & 3 & -190 & 2 & -192 \\
\hline 86.8 & 62.0 & 6.01 & -181 & 1 & -186 & 1 & -183 & 1 & -185 \\
\hline 87.5 & 62.4 & 5.40 & -179 & 0 & -182 & 0 & -179 & 1 & -181 \\
\hline 88.5 & 62.9 & 3.23 & -177 & 1 & -180 & 1 & -178 & 0 & -180 \\
\hline 09.2 & 63.3 & 3.06 & -176 & 2 & -183 & 2 & -179 & 2 & -181 \\
\hline 90.3 & 63.9 & 4.43 & -179 & 0 & -191 & 0 & -185 & 0 & -187 \\
\hline 92.0 & 65.5 & 3.82 & -188 & 0 & -193 & 0 & -190 & 0 & -192 \\
\hline 94.0 & 67.3 & 3.52 & -184 & 1 & -187 & 1 & -185 & 1 & -187 \\
\hline 96.0 & 69.2 & 5.25 & -190 & 2 & -195 & 2 & -193 & 2 & -195 \\
\hline
\end{tabular}

(C) 2019 American Geophysical Union. All rights reserved. 


\begin{tabular}{|c|c|c|c|c|c|c|c|c|c|}
\hline 98.0 & 71.0 & 4.99 & -188 & 3 & -191 & 3 & -188 & 3 & -191 \\
\hline 100.0 & 72.9 & 4.90 & -186 & 2 & -190 & 1 & -187 & 1 & -189 \\
\hline 104.1 & 76.6 & 6.57 & -189 & 0 & -191 & 2 & -189 & 1 & -191 \\
\hline 110.3 & 80.6 & 4.28 & -179 & 0 & -181 & 0 & -179 & 0 & -181 \\
\hline 112.2 & 81.6 & 6.40 & -191 & 1 & -191 & 1 & -192 & 1 & -193 \\
\hline 114.3 & 82.4 & 6.17 & -183 & 1 & -190 & 1 & -186 & 1 & -186 \\
\hline 115.9 & 83.0 & 4.78 & -186 & 3 & -186 & 1 & -187 & 2 & -187 \\
\hline 118.0 & 83.8 & 7.02 & -184 & 2 & -190 & 0 & -187 & 0 & -187 \\
\hline 119.9 & 84.5 & 7.25 & -187 & 1 & -195 & 3 & -191 & 2 & -190 \\
\hline 122.0 & 85.3 & 8.63 & -187 & 1 & -196 & 3 & -191 & 2 & -191 \\
\hline 124.1 & 86.1 & 6.56 & -192 & 1 & -197 & 1 & -195 & 1 & -195 \\
\hline 125.9 & 86.7 & 9.57 & -189 & 0 & -193 & 1 & -191 & 1 & -191 \\
\hline 128.1 & 87.2 & 5.73 & -189 & 0 & -194 & 2 & -191 & 1 & -192 \\
\hline 20 & 88.3 & 2.44 & -175 & 1 & -178 & 0 & -176 & 1 & -181 \\
\hline 134.3 & 89.3 & 1.97 & -183 & 0 & -184 & 0 & -184 & 0 & -190 \\
\hline 136.0 & 90.1 & 2.10 & -182 & 2 & -185 & 2 & -184 & 2 & -191 \\
\hline 138.0 & 91.1 & 1.69 & -179 & 0 & -178 & 0 & -179 & 0 & -186 \\
\hline 140.0 & 92.1 & 1.20 & -175 & 1 & -176 & 2 & -176 & 0 & -183 \\
\hline 141.9 & 93.5 & 1.18 & -176 & 1 & -184 & 0 & -180 & 0 & -186 \\
\hline 143.6 & 94.7 & 1.56 & -179 & 1 & -177 & 0 & -178 & 0 & -184 \\
\hline 152.5 & 100.6 & 2.05 & -179 & 1 & -181 & 1 & -180 & 1 & -186 \\
\hline 150.1 & 101.0 & 1.12 & -176 & 2 & -174 & 2 & -176 & 2 & -182 \\
\hline
\end{tabular}

() 2019 American Geophysical Union. All rights reserved. 
Table 2. Hydrogen isotope ratios of long-chain alkenones $\left(\delta^{2} \mathrm{H}_{\mathrm{C} 37}\right)$ for the most recent sample and for Last Glacial Maximum (LGM; $\left.21 \mathrm{ka}\right)$ from this study and previously published records of $\delta^{2} \mathrm{H}_{\mathrm{C} 37}$ ratios (Pahnke et al., 2007; Kasper et al., 2014; Kasper et al., 2015; Petrick et al., 2015; Simon et al., 2015). The differences in $\delta^{2} \mathrm{H}_{\mathrm{C} 37}$ ratios between LGM and the modern in all records suggest a larger $\delta^{2} \mathrm{H}_{\mathrm{C} 37}-$ salinity sensitivity that previously reported in culture or environmental analyses, except for the Mozambique Channel record (Kasper et al., 2015) which does not record glacial to interglacial shifts.

\begin{tabular}{|c|c|c|c|c|c|c|}
\hline & \multicolumn{2}{|c|}{ Modern } & \multicolumn{2}{|c|}{ LGM } & & \\
\hline Paper & Age (ka) & $\begin{array}{c}\text { Ice volume } \\
\text { corrected } \\
\delta^{2} \mathrm{H}_{\mathrm{C} 37}(\% \mathrm{o} \\
\text { vs } \\
\text { VSMOW }) \\
\end{array}$ & $\begin{array}{l}\text { Age } \\
(\mathrm{ka})\end{array}$ & $\begin{array}{c}\text { Ice volume } \\
\text { corrected } \\
\delta^{2} \mathrm{H}_{\mathrm{C} 37}(\% \mathrm{o} \\
\text { vs } \\
\text { VSMOW }) \\
\end{array}$ & Difference & $\begin{array}{l}\text { Sensitivity } \\
\text { for shift of } \\
2 \mathrm{psu}^{-1}\end{array}$ \\
\hline Pahnke et al., 2007 & 0.3 & -221 & 21.1 & -205 & 16 & 8 \\
\hline Kasper et al., 2014 & 3.5 & -192 & 21.1 & -180 & 12 & 6 \\
\hline Kasper et al., 2015 & 0.8 & -189 & 21.3 & -203 & -14 & -7 \\
\hline Petrick et al., 2015 & 2.7 & -205 & 23.1 & -187 & 18 & 9 \\
\hline Simon et al., 2015 & 2.0 & -195 & 20.1 & -186 & 9 & 4.5 \\
\hline ODP 1234 & 1.0 & -195 & 21.4 & -184 & 11 & 5.5 \\
\hline & Kegres & Equatior & $\Pi_{C}$ & linity Relat & aship & \\
\hline Paper & Type & Slope & $\mathrm{SE}$ & Intercept & $\mathrm{SE}$ & number \\
\hline $\begin{array}{c}\text { Schouten et al. } \\
\text { (2006) }\end{array}$ & Culture & 4.8 & 0.7 & -347 & 19.4 & 11 \\
\hline Gould et al. (2019) & SPM & 4.2 & 1.0 & -340 & 37.0 & 63 \\
\hline Weiss et al. (2019) & Sediment & 1.3 & 0.1 & -227 & 3.6 & 95 \\
\hline
\end{tabular}




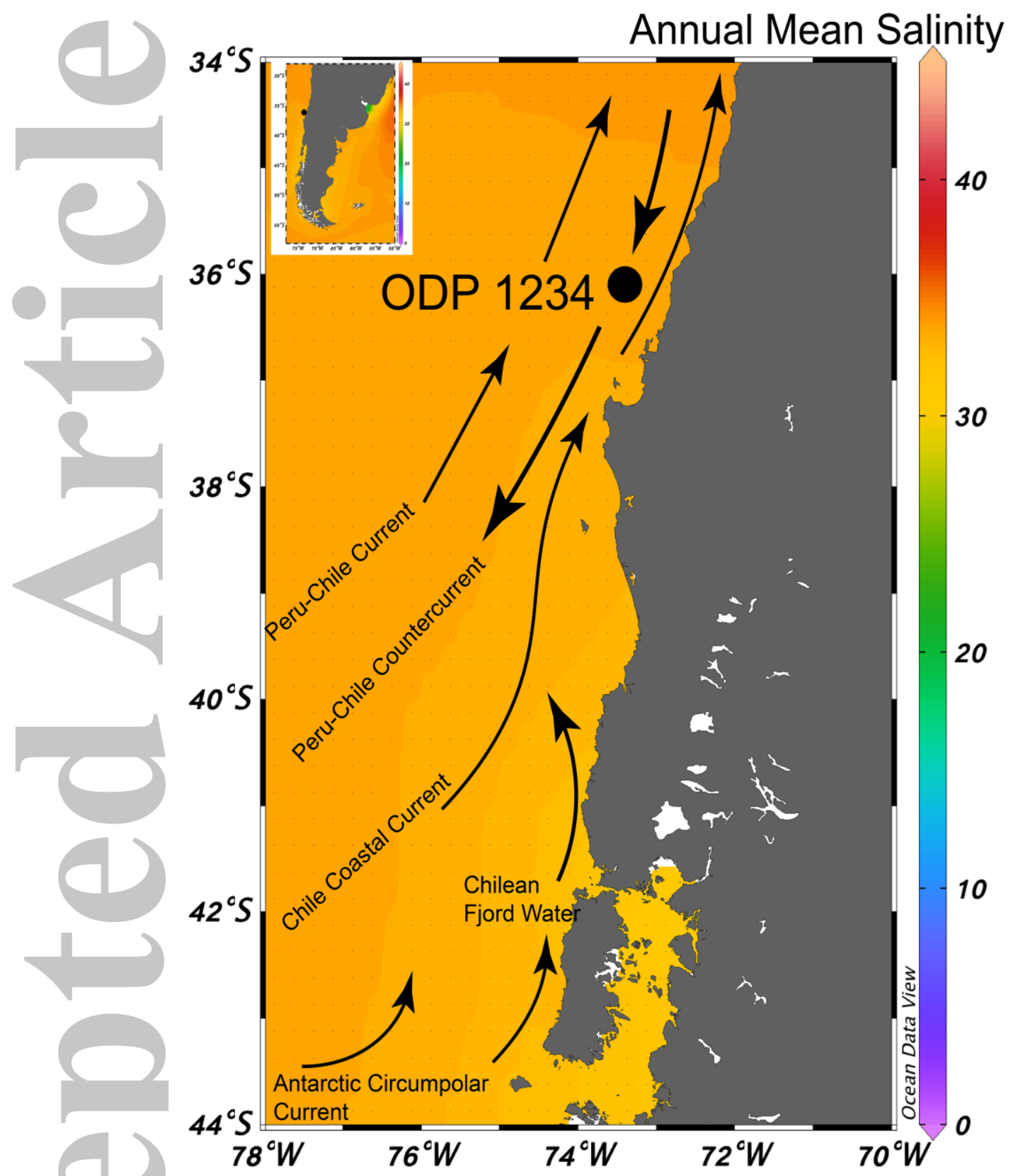

Figure 1. Map showing the environmental setting of ODP 1234. The core location is influenced by the Northward Peru-Chile Current and Chilean Coastal Current, and the southward Peru-Chile Countercurrent. In the south, Antarctic Circumpolar waters potentially feed into the PCC, CCC, and PCCC, and Chilean Fjord Waters can also enter the system from the southeast. 
a

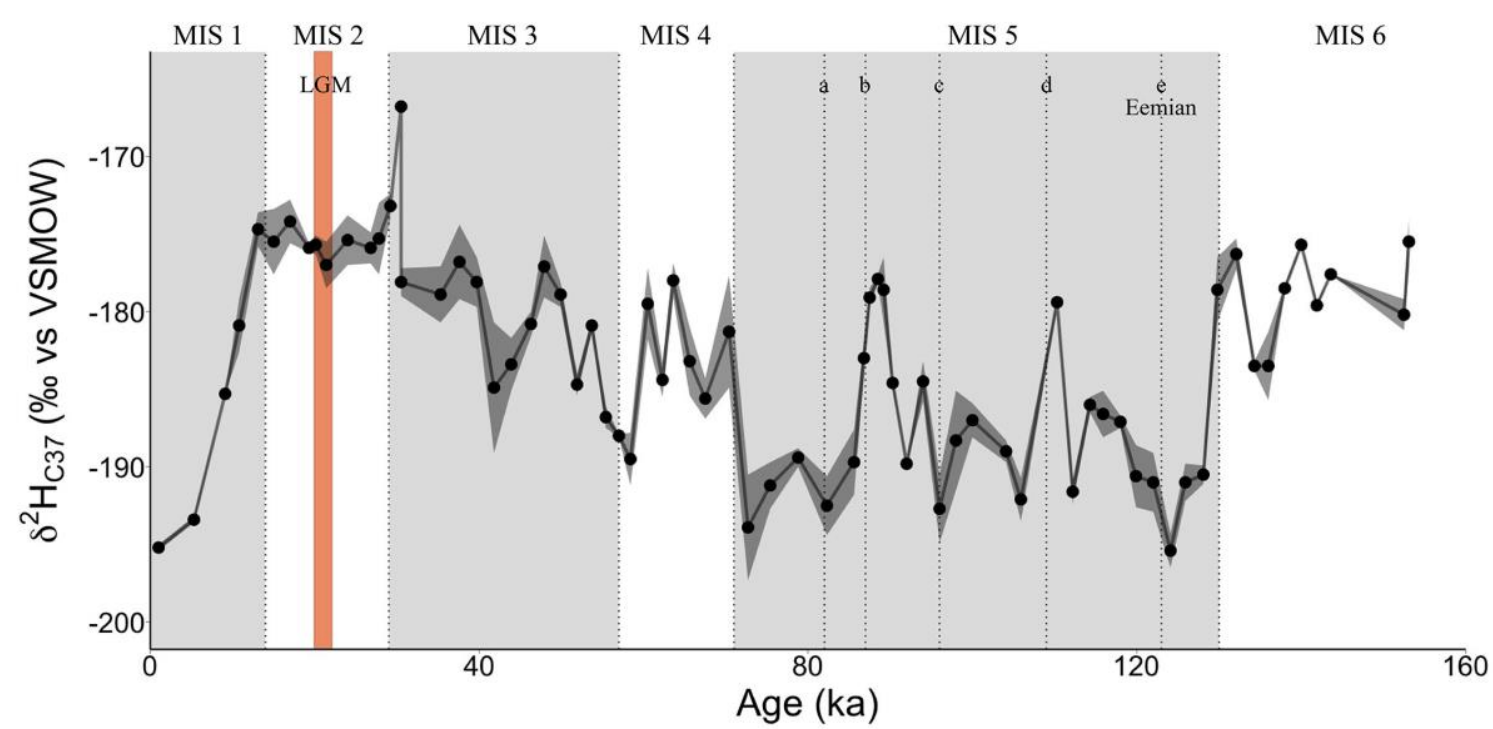

b

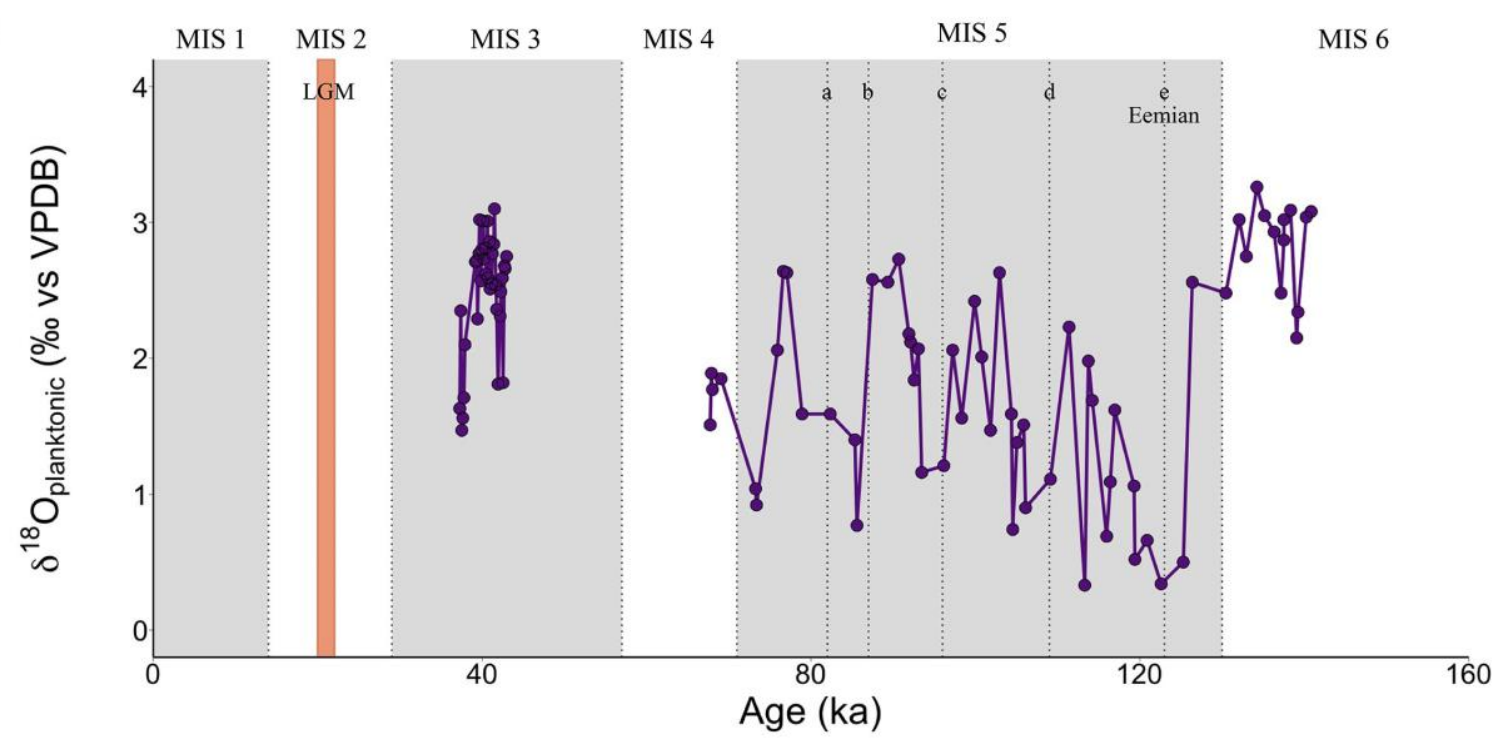

Figure 2. (a) Record of $\delta^{2} \mathrm{H}_{\mathrm{C} 37}$ ratios and (b) $\delta^{18} \mathrm{O}$ ratios of planktonic foraminifera over the last $\sim 150 \mathrm{kyr}$ (adapted from de Bar et al., 2018) plotted with marine isotope stages 1-6. Grey shading in (a) represents the standard deviation of duplicate isotope measurements. $\delta^{2} \mathrm{H}_{\mathrm{C} 37}$ and $\delta^{18} \mathrm{O}$ ratios follow the same trends, with more enriched isotope ratios corresponding to colder time periods and more depleted isotope ratios corresponding to warmer climates. 


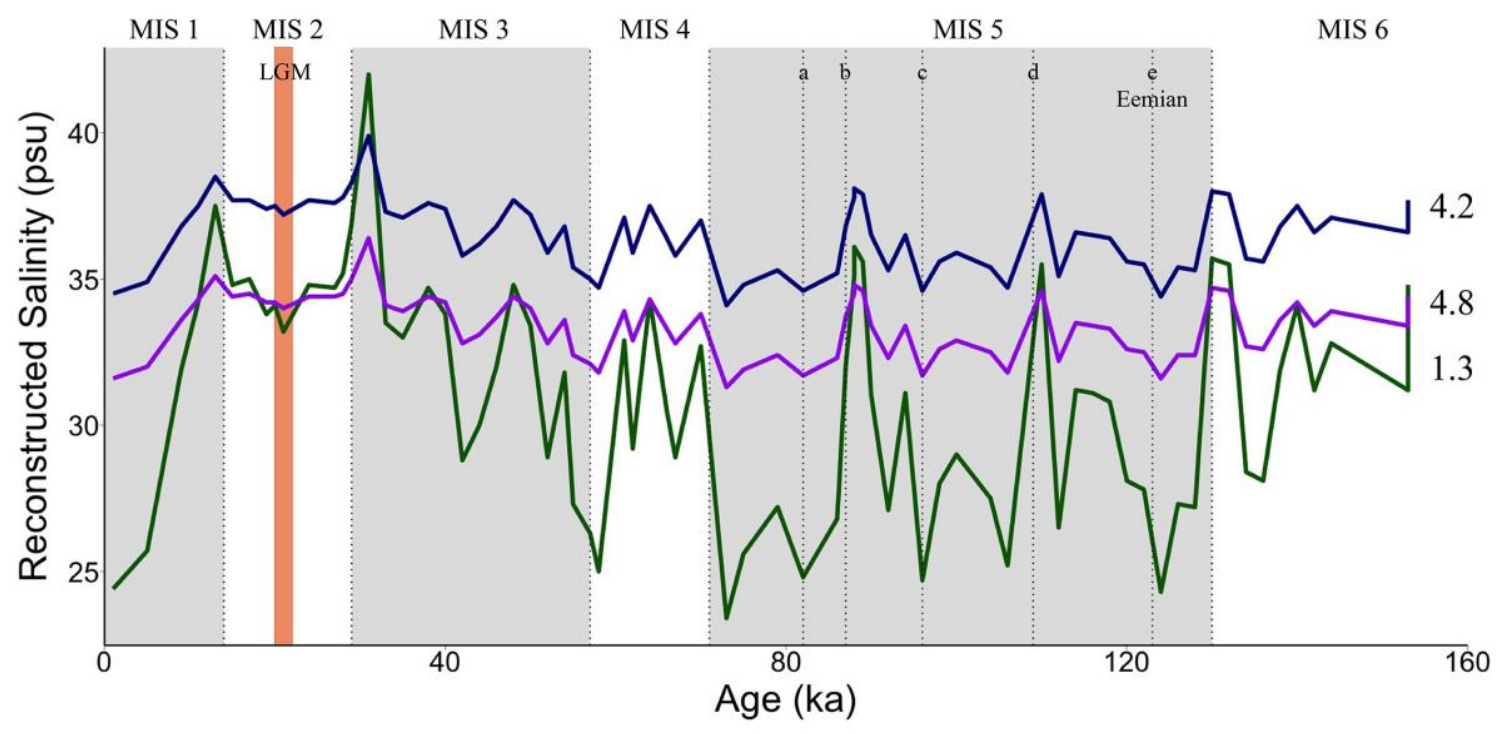

Figure 3. Reconstructed salinities (psu) for ODP 1234 using the marine surface sediment calibration from Weiss et al. (2019) in green with a slope of 1.3, the linear regression equation from Schouten et al. (2006) batch culture experiment growing Emiliania huxleyi in light purple with a slope of 4.8, and the SPOM calibration from Gould et al. (2019) in dark blue with a slope of 4.2. The surface sediment calibration yielded a salinity shift of $\sim 19 \mathrm{psu}$ over the entire record, whereas the E. huxleyi and SPOM equations covered a more reasonable salinity shift of $\sim 5$ psu across the record. The SPOM equation (Gould et al., 2019) provided the best estimate for the most modern sample of $34 \mathrm{psu}$, aligning with the measured salinity of 33.8 psu at ODP 1234 . 

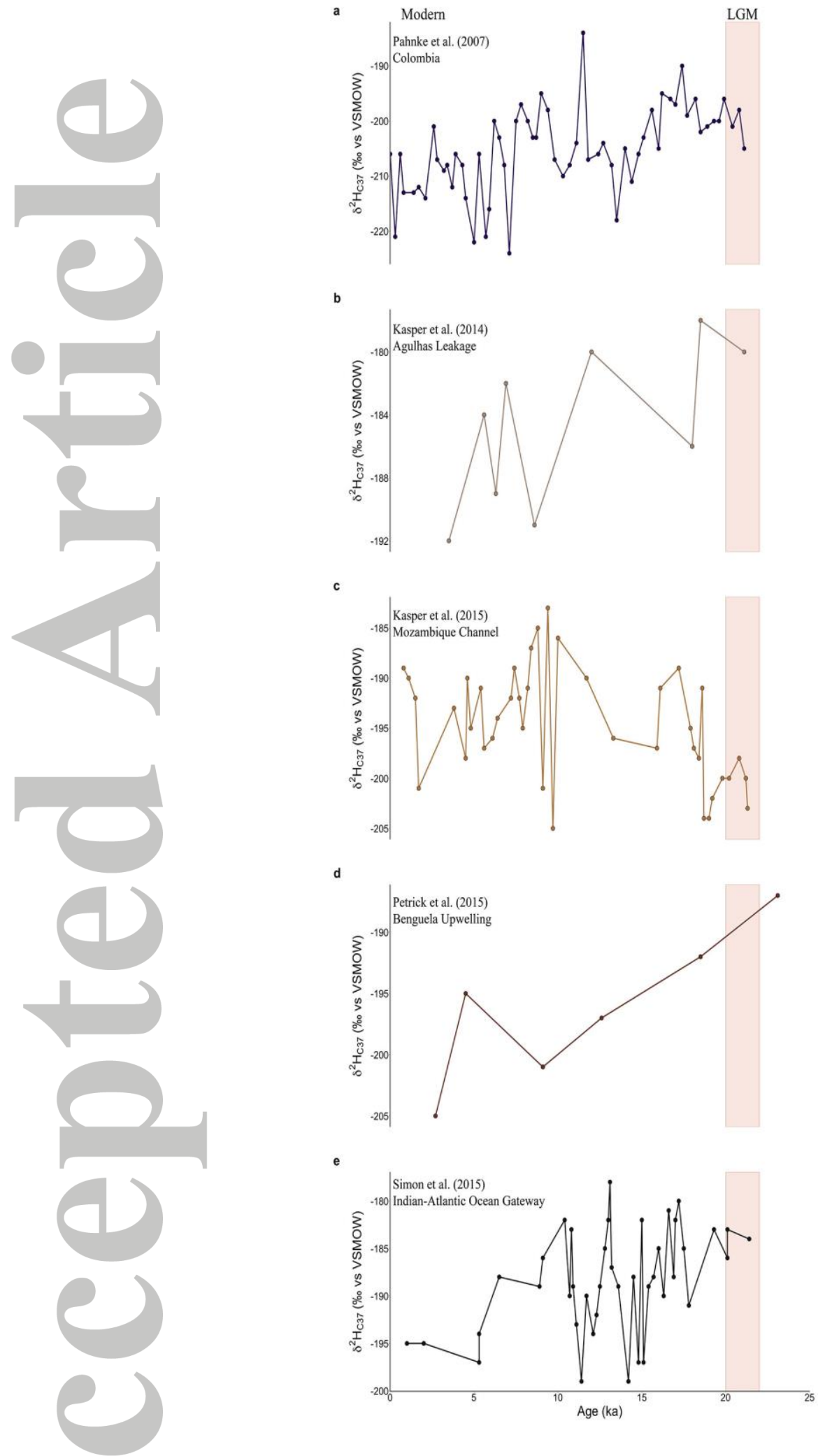

Figure 4. Records of $\delta^{2} \mathrm{H}_{\mathrm{C} 37}$ ratios from previously published records (Pahnke et al., 2007; Kasper et al., 2014, 2015; Petrick et al., 2015; Simon et al., 2015) covering the Last Glacial Maximum (LGM) until the present. Note the different scales for the y-axis. All records show more enriched values for the LGM and more depleted values for the modern, except for (c) the Mozambique Channel record from Kasper et al. (2015). 